\title{
Patterns of Governance Structures in Trade Associations and Unions
}

\author{
Georg von Schnurbein*
}

Draft, November 2008.

\begin{abstract}
Governance of nonprofit organizations has become a major topic in research and practice. Most research is concentrated on welfare oriented organizations, and disregards other types of nonprofits. This article examines the governance structures of trade associations and unions as a special type of nonprofit organization. Analysis is based on a qualitative case study survey among 30 Swiss trade associations. The results distinguish four different categories of governance: satellite governance, delegate governance, executive governance, and inner circle governance.
\end{abstract}

\section{Keywords:}

nonprofit governance, association, governance structure, checks and balances, representation, members

*Georg von Schnurbein, Centre for Philanthropy Studies (CEPS), University of Basel, Rheinsprung 9, 4051 Basel, Switzerland, Phone: +41 6126734 63, Mail: georg.vonschnurbein@unibas.ch, www.ceps.unibas.ch 
Governance problems in nonprofits have been discussed strongly over the last decade. Most research has concentrated on service-based organizations such as hospitals, quasi-governmental agencies or social service activities (Ostrower and Stone, 2006). These organizations are confronted with a discrepancy between their clients and those who finance the services they offer. The majority of governance definitions and mechanisms address such organizations and tend towards a wide orientation in order to address all stakeholders.

In contrast, little effort has been placed on member-oriented organizations such as voluntary associations, trade associations or professional associations (Friedman and Phillips, 2004; Tschirhart, 2006). An association is usually described as a formally organized group of people with membership structures and voluntary action that promotes a common interest (Harris, 1998). The purpose of trade associations and unions primarily benefits members, e.g. trade unions that fight for good working conditions. In associations, members perform several roles at the same time, which puts them into a accentuated position compared to other stakeholders. Specifically, members are the legitimating body, contributors, volunteer members, clients of services, and beneficiaries of public goods provided by the association (Schwarz, 2005). The accumulation of roles held by one stakeholder group may affect the structure of an association.

In our understanding, structures consist of the formal rules of coordination and participation within the organization (Kieser and Kubicek, 1992). In various cases, literature gives insight into how structures influence the management of associations. Young, Bania and Bailey (1996) analyzed the influence of structures on the accountability of umbrella organizations and their local affiliates. Coleman and Grant (1988) argued that centralized and representative structures give trade associations a higher influence on politics. Another study gave insight that structure influences the way an association is perceived and interacts with individuals and other organizations (Standley, 2001). Schwarz (1996) shows that associations tend to formulate their strategy according to their structure rather than vice versa.

\section{Research Focus}

Knoke (1990) differentiates between administrative structure and governance structure as two functionally distinct yet interdependent components of an organization. The study presented here concentrates on the governance structures of trade associations and unions. The basic assumption is that structural dimensions influence the way governance is executed and that these structural dimensions determine the stakeholders involved. Therefore, research focuses on how association governance is influenced by specific structural dimensions and whether different patterns of governance can be detected. Special interest is placed on the question of how members are integrated into the governance structures. Since governance theories or models that target associations are rare, this study will partly relay findings and models applied to business or to nonprofits other than associations (Tschirhart, 2006). 
In comparative studies on nonprofits, Switzerland has been labeled a corporatist country (Anheier, 2001; Anheier and Daly, 2007). Corporatist policies imply that nonprofits are by and large in some form of subsidiary relationship with the state. This is noticeable particularly in the social welfare system, but also in how the economy is organized. In total there are 754 trade associations and unions in Switzerland with little more than 7'000 employees. The importance of these organizations can not be assessed by their economic relevance but rather by their political and social influence. In Switzerland, associations have the constitutional right of voice in all matters of economic policy and are involved in its execution (Linder, 1999). Furthermore, associations fulfill some important tasks for their members such as industrial training or collective negotiations. Through these tasks they exert influence on society as a whole (Schnyder, 2000). Until now, Swiss trade associations and unions have been the subject of only few academic studies (Kriesi, 1995; Schnyder, 2000).

In this study the governance of (Swiss) trade associations and unions is analyzed as an example of member oriented organizations. Although there might be a difference between associations operating in different fields of activities, with different purposes, and with different geographical scopes, their structural dimensions are comparable to some extent (Harris, 1998).

\section{Dimensions of Associational Structure}

In order to measure structure we choose three different dimensions used in other studies (Akers and Campbell, 1970; Bailey, 1992; Fry, 1982): centrality, size, and type of members. Centrality captures the degree to which decision making and strategic alignment are centrally managed or shared with peripheral units (Schwarz, 2005; Van de Ven and Ferry, 1980). In the context of trade associations and unions a general distinction can be made between centralist and peripheral structures. In a "central structure" the organization is directed by a core unit and the affiliates are subordinate to the national organization. Respectively, a "federal structure" consists of similar autonomous affiliate organizations belonging to a national organization. Young, Nania and Bailey (1996) found comparable structural types among umbrella organizations, but their most common structure, what they called "trade structure", refers heavily to umbrella organizations and is therefore not helpful to this study.

Another variable of structure is organizational size (Blau and Schoenherr, 1971). Especially, in combination with questions on governance the organizational size plays an important role as structural determinant (Brown, 2005; Cornforth and Simpson, 2002; Murray, Bradshaw and Wolpin, 1992). The size of an association can be measured by number of staff, organizational budget, and number of members (Knoke, 1990). According to the research focus of this study on the member influence on governance, the organizational size will be measured by the number of members.

The last structure component is the type of members. There are different ways to distinguish membership (Tschirhart, 2006), but what is of interest for this study is the distinction between individual and organizational members (Knoke, 1990). This differentiation is of interest in terms of contributions, volunteer 
activities, and density. Individuals usually pay their contribution themselves, whereas in organizations, e.g. enterprises or nonprofits, the contribution is paid by the organization and one or more individuals represent the organization in the association. In trade unions and professional associations members can only volunteer in their spare time or - especially in associations for self-employed professions - they have to accept a loss of income. Whereas for most representatives of organizations their involvement in the association is part of the job description. Finally, Streeck (1991) reported a lower density in trade associations than in unions due to a higher degree of fragmented interests in trade associations.

\section{Governance in Trade Associations and Unions}

We define governance as a set of instruments and mechanisms that support the (nonprofit) board of directors in its global leadership of the organization and assure the completion of the purpose, the legitimacy, and the accountability of a nonprofit organization. Particularly, nonprofit governance establishes operational guidelines for the interaction between the board of directors on the one side and the internal and external stakeholders, on the other side.

The appearance of governance-problems in nonprofit organizations is widely acknowledged and has led to a debate on governance in nonprofits (Drucker, 1990; Bradshaw, Murray and Wolpin, 1992; Golensky, 1993; Alexander and Weiner, 1996; Holland and Jackson, 1998; Carver, 1997; Houle, 1997; Ostrower and Stone, 2006). According to the new institutional economics, a governance problem in an organization occurs if at least one of the following criteria has to be managed (Hart 1995): the division of ownership and control and the vertical integration. Based on the premises of agency theory and transaction cost theory the following section will discuss how these criteria occur in associations.

The first criterion deals with the division of ownership and control, commonly discussed as the agency problem (Jensen and Meckling, 1976). Agency problems arise when an individual (agent) works on behalf of another individual or group of individuals (principal) in order to fulfill their interests. Referring to existing concepts, the governance structure of associations does neither correspond to that of for-profits nor to that of service-based nonprofits. While shareholders of a for-profit have property rights, the members of a nonprofit organization do not, because the assets of a nonprofit organization are held exclusively for the purpose for which they were intended (Bryce, 2006).

In service-based nonprofits the definition of the principal is discussed controversially. On the one hand, Fama and Jenson (1983) defined the donors as the relevant principals as they expect that their donations will be used in an efficient way. Callen, Klein and Tinkelman (2003) supported this view empirically with a survey of 123 nonprofit organizations. On the other hand, the beneficiaries can be defined as the owners of the organization because they have the highest interest in a good offer of services (Abzug and Galaskiewicz, 2001). This discussion does not correspond to trade associations as unions, because their members are both contributors and primary beneficiaries (Schwarz, 1996). 
Therefore, members could be compared with shareholders because of their voting rights and their legitimating role. Instead, they differ not only because of the lack of property rights, but also because of their heterogeneous interests. While the interest of shareholders is dominantly monetary, the interest of the members varies among the different purposes of the association. Whereas one member of a trade association demands good lobbying, another might prefer high quality trainings, and yet another good legal services. Young (1985) argues that associations are founded by individuals who want to maximize their profit. In other words, joining an association is a calculated self-interest decision and it does not refer to collective goals of the association (Watson, 1988). Simultaneously, associations do not always exclusively pursue membership goals, but also provide benefits for the wider public (Lohman, 1992; O’Neill, 1994). Trade associations develop security norms or industry standards, they organize professional education, they provide expert knowledge for politics, etc. Therefore, member satisfaction is one but not the only aim of the association.

Another concern of agency problems in organizations is accountability (Keasey and Wright, 1997). There is ambiguity about how accountability can be realized and sustained in a nonprofit organization. External approaches postulate stricter laws and regulation - especially soft law - whereas internal approaches favor instruments such as total quality management, client orientation or management by objectives (Holland, 2002). As mentioned above, Young, Bania and Bailey (1996) show that different structures have an influence on the accountability of the association. They show that affiliates in centralized structures have less influence over the national office than affiliates in federal structures.

Another explanation for governance problems is the necessity of vertical integration. In the case of nonprofit organizations, the absence of clear market regulations leads to a high importance of hierarchical structures within the nonprofit organizations (Herzlinger, 1998). According to the transaction cost theory, the hierarchical structures should guarantee a sufficient extent of transparency and control (Williamson, 1996). Therefore, one of the major concerns of nonprofit governance is the collaboration of the board of directors and the CEO. Golensky (1993) identifies four decisive factors: board-executive communication, executive assets, board-executive congruence, and board-executive role expectations. The different possible constellations of power and their impact on governance have also been analyzed by Murray, Wolpin and Bradshaw (1992). The CEO-dominated board is what Cornforth (2001) calls a rubberstamp board. It has no major influence on the organization and exists more or less in pretence of a complete organizational structure. A chair-dominated board is heavily affected - not to say controlled - by its elected leader, the chairman or the president. A third pattern is the fragmented power board. It can be characterized by conflicts and different ideologies within the board. The opposite pattern is the power-sharing board, based on a "strong ideological commitment to the values of equality and democracy" (Murray, Wolpin and Bradshaw, 1992, p. 168). The last - and probably worst - pattern is the powerless board. Such a board is locked between aimlessness and uncertainty. It has no clearly defined function, is poorly organized and works more or less unsteadily. Generally, we can expect that there is always someone who dominates the board. 
Brown and Iverson (2004) show, that governance structures give an indication of the organization's strategies. This promotes the idea that only those who are involved in the governance structures can actively affect strategic decision-making. If the members of a trade association or union are represented effectively by the elected board, there should be a lower need of additional governance instruments. But this connection cannot be captured directly as suitable measures are missing (Forbes, 1998). Herman and Heimovics (1990) conclude that organizational reality is influenced by the expectations, interests and benefits of each actor and the environment. Based on this insight, several empirical surveys analyzed the expectations of individuals and the mutations of structures over time (Fletcher, 1992; Preston and Brown, 2004; Wood, 1992). The aim is to find a system of checks and balances that includes not only these two actors, but also other internal and external stakeholders (Saidel and Harlan; 1998). Saidel (1998) distinguished advisory groups as important governance instruments with internal and external effects on the organization. In particular, they complement governance tasks carried out by the board of directors.

Based on this literature review the following study analyzes how the structure of a trade association or union influences the way governance is executed in this kind of organization. Namely, different patterns of association governance will be defined through this analysis.

\section{The Study}

Based on our definition of governance we drew up a qualitative exploratory survey with a sample of 30 trade associations and unions in Switzerland. The associations are analyzed and reviewed in holistic case studies using the organizations' communication and publications, statutes, annual reports, and external information resources. Special emphasis is put on the size of the board, the number of advisory groups, the overall structure, and the formal dispersion of tasks among members, local organizations and the national unit. The sample is structured by the size of the organizations (measured by number of members). Additionally, the associations are chosen from different industries. They represent industries such as hospitals, handcraft, banking, heavy industry, service industries, and self-employed professions. The 30 case studies can be further divided into 14 industry associations, 9 professional associations, 4 unions, and 3 umbrella organizations, one for trade associations and two for unions (see table 1). Their member size ranged from 16 to 30000 (median: 750 ) in associations with (mostly) organizational members and from 2224 to 203000 (median: 14244) in associations with (mostly) individual members. In the Swiss context, a trade association (resp. union or professional association) can be considered small with less than 100 members (10000) and large with more than 1000 members (100000). Based on their statutes, 16 associations have centralistic structures, 14 have federal structures. For example, indicators for centrality were strong hierarchical relationships between the core unit and the affiliates, a low influence of regional boards on central election procedures, the absence of paid staff in regional organizations, and a homogeneous corporate design. The board size ranges from 4 to 40 with an average of 16.4 and a median of 9 . In all cases with more than 20 board members a smaller executive committee with 3 to 5 board members exists. Also, the number of advisory groups to the board varied 
strongly. Some associations have no advisory groups, others have many of them. Here, the average is 5.6 and the median is 4 .

\section{Table 1: descriptive findings on this sample}

\begin{tabular}{|c|c|c|c|c|c|c|c|}
\hline$\#$ & $\begin{array}{l}\text { kind of } \\
\text { organization }\end{array}$ & $\begin{array}{l}\text { Size by } \\
\text { members }\end{array}$ & $\begin{array}{l}\text { Size } \\
\text { of } \\
\text { board }\end{array}$ & $\begin{array}{l}\text { Advisory } \\
\text { Groups }\end{array}$ & $\begin{array}{l}\text { Type of } \\
\text { structure }\end{array}$ & $\begin{array}{l}\text { type of } \\
\text { members }\end{array}$ & $\begin{array}{l}\text { member } \\
\text { assembly }\end{array}$ \\
\hline 1 & $\begin{array}{l}\text { industry } \\
\text { association }\end{array}$ & 17 & 9 & 4 & centralistic & organizations & $\begin{array}{l}\text { general } \\
\text { assembly }\end{array}$ \\
\hline 2 & $\begin{array}{l}\text { industry } \\
\text { association }\end{array}$ & 77 & 19 & 36 & centralistic & organizations & $\begin{array}{l}\text { general } \\
\text { assembly }\end{array}$ \\
\hline 3 & $\begin{array}{l}\text { industry } \\
\text { association }\end{array}$ & 110 & 9 & 5 & centralistic & organizations & $\begin{array}{l}\text { general } \\
\text { assembly }\end{array}$ \\
\hline 4 & $\begin{array}{l}\text { industry } \\
\text { association }\end{array}$ & 390 & 13 & 19 & centralistic & organizations & $\begin{array}{l}\text { general } \\
\text { assembly }\end{array}$ \\
\hline 5 & $\begin{array}{l}\text { industry } \\
\text { association }\end{array}$ & 971 & 7 & 0 & federalist & organizations & $\begin{array}{l}\text { delegates' } \\
\text { assembly }\end{array}$ \\
\hline 6 & $\begin{array}{l}\text { industry } \\
\text { association }\end{array}$ & 2375 & 10 & 2 & federalist & organizations & $\begin{array}{l}\text { delegates' } \\
\text { assembly }\end{array}$ \\
\hline 7 & $\begin{array}{l}\text { industry } \\
\text { association }\end{array}$ & 3613 & 11 & 5 & federalist & organizations & $\begin{array}{l}\text { delegates' } \\
\text { assembly }\end{array}$ \\
\hline 8 & $\begin{array}{l}\text { industry } \\
\text { association }\end{array}$ & 46 & 8 & 0 & federalist & organizations & $\begin{array}{l}\text { delegates' } \\
\text { assembly }\end{array}$ \\
\hline 9 & $\begin{array}{l}\text { industry } \\
\text { association }\end{array}$ & 750 & 14 & 5 & centralistic & $\begin{array}{l}\text { mostly } \\
\text { organizations }\end{array}$ & $\begin{array}{l}\text { general } \\
\text { assembly }\end{array}$ \\
\hline 10 & $\begin{array}{l}\text { industry } \\
\text { association }\end{array}$ & 30000 & 20 & 3 & centralistic & $\begin{array}{l}\text { mostly } \\
\text { organizations }\end{array}$ & $\begin{array}{l}\text { delegates' } \\
\text { assembly }\end{array}$ \\
\hline 11 & $\begin{array}{l}\text { industry } \\
\text { association }\end{array}$ & 978 & 11 & 0 & centralistic & $\begin{array}{l}\text { mostly } \\
\text { organizations }\end{array}$ & $\begin{array}{l}\text { general } \\
\text { assembly }\end{array}$ \\
\hline 12 & $\begin{array}{l}\text { industry } \\
\text { association }\end{array}$ & 1722 & 5 & 8 & federalist & $\begin{array}{l}\text { mostly } \\
\text { organizations }\end{array}$ & $\begin{array}{l}\text { delegates' } \\
\text { assembly }\end{array}$ \\
\hline 13 & $\begin{array}{l}\text { industry } \\
\text { association }\end{array}$ & 507 & 18 & 0 & federalist & $\begin{array}{l}\text { mostly } \\
\text { organizations }\end{array}$ & $\begin{array}{l}\text { delegates' } \\
\text { assembly }\end{array}$ \\
\hline 14 & $\begin{array}{l}\text { industry } \\
\text { association }\end{array}$ & 2935 & 7 & 10 & federalist & $\begin{array}{l}\text { mostly } \\
\text { organizations }\end{array}$ & $\begin{array}{l}\text { delegates' } \\
\text { assembly }\end{array}$ \\
\hline 15 & $\begin{array}{l}\text { umbrella } \\
\text { organization }\end{array}$ & 16 & 30 & 5 & centralistic & organizations & $\begin{array}{l}\text { delegates' } \\
\text { assembly }\end{array}$ \\
\hline 16 & $\begin{array}{l}\text { umbrella } \\
\text { organization }\end{array}$ & 300 & 8 & 0 & centralistic & organizations & $\begin{array}{l}\text { general } \\
\text { assembly }\end{array}$ \\
\hline 17 & $\begin{array}{l}\text { umbrella } \\
\text { organization }\end{array}$ & 900 & 13 & 6 & centralistic & organizations & $\begin{array}{l}\text { general } \\
\text { assembly }\end{array}$ \\
\hline 18 & $\begin{array}{l}\text { professional } \\
\text { association }\end{array}$ & 2224 & 8 & 1 & federalist & individuals & $\begin{array}{l}\text { general } \\
\text { assembly }\end{array}$ \\
\hline 19 & $\begin{array}{l}\text { professional } \\
\text { association }\end{array}$ & 50000 & 40 & 4 & federalist & individuals & $\begin{array}{l}\text { delegates' } \\
\text { assembly }\end{array}$ \\
\hline 20 & $\begin{array}{l}\text { professional } \\
\text { association }\end{array}$ & 11500 & 7 & 1 & federalist & individuals & $\begin{array}{l}\text { delegates' } \\
\text { assembly }\end{array}$ \\
\hline 21 & $\begin{array}{l}\text { professional } \\
\text { association }\end{array}$ & 6000 & 4 & 2 & centralistic & individuals & $\begin{array}{l}\text { delegates' } \\
\text { assembly }\end{array}$ \\
\hline 22 & $\begin{array}{l}\text { professional } \\
\text { association }\end{array}$ & 11663 & 20 & 12 & centralistic & $\begin{array}{l}\text { mostly } \\
\text { individuals }\end{array}$ & $\begin{array}{l}\text { general } \\
\text { assembly }\end{array}$ \\
\hline
\end{tabular}




\begin{tabular}{|l|l|l|l|l|l|l|l|}
\hline 23 & $\begin{array}{l}\text { professional } \\
\text { association }\end{array}$ & 14244 & 9 & 0 & federalist & $\begin{array}{l}\text { mostly } \\
\text { individuals }\end{array}$ & $\begin{array}{l}\text { delegates' } \\
\text { assembly }\end{array}$ \\
\hline 24 & $\begin{array}{l}\text { professional } \\
\text { association }\end{array}$ & 6200 & 32 & 16 & centralistic & $\begin{array}{l}\text { mostly } \\
\text { individuals }\end{array}$ & $\begin{array}{l}\text { general } \\
\text { assembly }\end{array}$ \\
\hline 25 & $\begin{array}{l}\text { professional } \\
\text { association }\end{array}$ & 102459 & 9 & 4 & federalist & $\begin{array}{l}\text { mostly } \\
\text { individuals }\end{array}$ & $\begin{array}{l}\text { delegates' } \\
\text { assembly }\end{array}$ \\
\hline 26 & $\begin{array}{l}\text { professional } \\
\text { association }\end{array}$ & 5750 & 13 & 4 & centralistic & $\begin{array}{l}\text { mostly } \\
\text { individuals }\end{array}$ & $\begin{array}{l}\text { general } \\
\text { assembly }\end{array}$ \\
\hline 27 & union & 50000 & 37 & 4 & centralistic & individuals & $\begin{array}{l}\text { delegates' } \\
\text { assembly }\end{array}$ \\
\hline 28 & union & 15000 & 20 & 6 & centralistic & individuals & $\begin{array}{l}\text { delegates' } \\
\text { assembly }\end{array}$ \\
\hline 29 & union & 37000 & 40 & 3 & federalist & individuals & $\begin{array}{l}\text { delegates' } \\
\text { assembly }\end{array}$ \\
\hline 30 & union & 203000 & 40 & 4 & federalist & individuals & $\begin{array}{l}\text { delegates' } \\
\text { assembly }\end{array}$ \\
\hline
\end{tabular}

In a second step, ten associations with varying characteristics were chosen for intensive face-to-face interviews with three representatives for each organization: one member of the board, one member of management and one member representative who was not a board member. This research design should allow for gathering different opinions on the same subject, and comparing and analyzing the position of a specific subgroup, for instance management, board, members, or organization types (Flick, 2000).

The relative newness of governance research in member-oriented organizations supports the choice of qualitative methodology (Yin, 2003). Each of the selected interviewees received a letter that explained the research setting. For practitioners in Switzerland, governance is a completely new construct (no German translation of governance exists). Therefore, the semi-structured questionnaire had to provide some general ideas and models of governance in order to generate comparable data (Kepper, 1996). The questionnaire contained 46 questions on four different topics. Firstly, there are several questions about governance in general and the interviewee's opinion on governance. Secondly, the composition, structure and functioning of the board is questioned in detail. Thirdly, the perception of the relation and the collaboration of board and management are considered. Detailed information about the role of the CEO in board meetings and the advisory role of the board are requested. Fourthly, the respondents were asked about the relationship between the board and the association members. The questions for this topic focused on election procedures, formal and informal communication from both sides, and general questions on membership.

Altogether only 27 interviews could be gathered, because in one organization only the CEO was willing to respond and in another organization no board member wanted to participate. The interviews were conducted in the spring of 2006 and were then transcribed, coded and analyzed through a summarizing interpretation and with the software maxqda2. Considering the size and nature of this sample, caution is suggested in generalizing the findings of the study. Further research should verify the robustness of the results.

5. Findings related to structural dimensions and governance 
According to the literature on agency problems and power distribution presented above, structural dimensions have an influence on governance when questions of representation (who is responsible to whom?) and of checks and balances (who governs whom?) have to be solved.

Representation. The board of directors is elected by the members in order to preserve their interests in the strategic decision process. However, gathering the seldom homogenous interests and expectations of the members is not an easy task for the board. Most members consider themselves clients rather than contributors. They evaluate the association's performance in respect to service delivery and quality, not to its ability to follow a longer term strategy (Harris, 1998).

Interviewees from eight of the ten interviewed associations reported that the board composition in their association is more influenced by representation than by work experience. They have written or unwritten rules regarding board composition, e.g. included are the most important members, the different regions, or the different member groups. Additionally, board members must be members of the association, a rule that excludes the possibility of independent directors. These mechanisms are set up to ensure a close connection between the members and the board.

Especially, in associations with individual members the number of board members is significantly higher than in other trade associations. On the one hand, a highly diverse representation results in a large number of board members, which often leads to a prolonged decision making process. On the other hand, a small board leads to a lack of legitimacy, because the members are not well enough represented. In one industry association the board members represented $90 \%$ of the national market share!

Looking at board composition the survey reveals that the representation of the members is more important than professional competence. The following quote of a board member of an industry association gives some insight on the nomination criteria.

We choose board members in such a way, that they cover a broad occupational field. Sometimes, this makes it difficult. We also try to have board members that are regional or national politicians. Thirteen Respondents (48.1\%) named representation criteria as very important. For eleven respondents $(40.7 \%)$ the professional competences were important, as well, but clearly in second order. Six respondents $(22.2 \%)$ from trade associations and associations of self-employed professions reported that the board members are expected to be successful in their job. Otherwise the association would loose credibility.

The legal instruments of members to execute their governance activity are elections and general assemblies. But the attendance at statutory meetings is weak. General assemblies usually are attended by less than 25 percent of the members, in delegate assemblies the participation is considerably better, usually over 75 percent. Thus, the legitimacy of decisions made by delegate assemblies is much higher. As shown in table 1, all associations with federal structure have a delegate assembly, whereas among centrally structured associations both kinds exist.

Another possible way for members to influence the decision making process is via committees and advisory groups. Most organizations have several advisory groups (up to thirty-six advisory groups!) where 
members as well as external experts are involved on a voluntary basis. The advisory groups prepare reports on special issues that are used by the board as a background for their decision making (Saidel, 1998). In one of the studied cases, the members were structured in functional advisory groups. For every advisory group, there was one board member that attended each meeting of the advisory group. Thus, the members had a direct connection to the board. In another case the chairmen of the regional sections constituted an advisory group, as the following statement of a member of an industry organization shows.

We made a good experience with the advisory group of regional chairmen. This group has no statutory rights, but it is a political committee. There, we have an attendance of 80 to 90 percent. That is much more than at the delegate assembly.

Such experiences where reported by other interviewees from organizations with similar non-statutory meetings. The higher attendance can be explained by the informative character of the meetings, whereas statutory meetings often are mainly concerned with elections and voting. Three of the nine board members interviewed mentioned ad hoc committees that are constituted for special topics by the board, additionally to present advisory groups.

In contrast to other research studies, no clear correlation between board size and organizational size can be reported. Surveys on charities report that the average board size increases with the size of the organization (Cornforth and Simpson, 2002; Kirkland and Sargant, 1995). The present study only allows drawing a clear distinction between associations with individual and organizational members. While the former with usually larger number of members show an average board size of 20.4, the latter with usually fewer members only have an average board size of 12. Instead, within the two categories, no clear tendency can be stated. This can be explained by the strong federalist voting procedures of most of the associations in Switzerland. Generally, the number of board members is linked to the number of existing regional sections, which is more or less the same in every association. If board elections are highly driven by representation criteria and by federalist voting procedures, the number of members has no large influence. This is a structural difference from other types of nonprofits where boards have a more inclusive role (Brown, 2002).

Checks and balances. In the literature review the vertical integration and power distribution within an organization was discussed as one of the main aims of governance structures (Drucker, 1990). As the CEO prepares and executes the decisions of the board, there is always the threat of completed staff-work by the professional corps (Irle, 1971). In the interviews, the representatives are asked to classify their association in one of the five models given by Murray, Wolpin and Bradshaw (1992). Two models were dominant in the results, namely the power-sharing structure and the CEO-dominated board. Six of the ten interviewed associations are led by a power-sharing structure between the board and the CEO; another three associations reported a CEO-dominated board. The respondents of the last association agreed on the Chairman-dominated board. 
In two cases the representatives of the board and management selected the power-sharing model while the member respondents chose the chair-dominated model. A variation which can be explained by the different point of views of the respondents. The external view of the members leads to the assumption that in these associations strategic decision making is done consensually, but the external communication is done only by the chairman. Many Swiss associations have the principle of collective responsibility of the board explicitly mentioned in the statutes.

A CEO-dominated model is most likely found in professional associations that have dominantly individuals as members. Here, the CEO has much more influence and the board is strongly dependent on the $\mathrm{CEO}$, as the following quote of a board member of a professional association demonstrates.

She [the CEO] plays an important role in the preparation of the agenda and the board meetings in general. Through preparing and the knowledge of every issue there is a high potential of influence on us. During the meeting she takes part in the discussions and points out different settings by offering detailed information. She articulates her opinion like a board member, but she has no voting right. This quote represents answers of sixteen respondents (59.3\%). Five respondents (18.5\%) from a professional association and two unions acknowledged a dominating influence of the CEO. These associations usually have a numerous and heterogeneous membership structure where the influence of each member is relatively small. Therefore, the board has difficulties in formulating the members' interests. In contrast, the executive staff contact the members as clients of the association more frequently and therefore often know the members' needs before the board does.

On the other hand, the power-sharing model was reported mostly by respondents of trade associations with dominantly corporate members. In these associations the members play a much more important role and therefore, their representatives in the board or in other committees have greater influence on the decision making process. Here, the membership structure is rather homogenous and small. Mostly, the board is made up of the (financially) important members. Thus, the board can better define and represent the members' interests.

Compared to the original study of Murray, Wolpin and Bradshaw (1992), the same two models are dominant, but in reversed order. An explanation for this difference might be the strength of the members in industry associations, but the reason could also be externally found in cultural differences between Canada and Switzerland. Additionally, the original study already pointed out that the three other models are probably less socially acceptable.

But a well-balanced power distribution is not only dependent on structural dimensions. The following quote highlights circumstances that have been analyzed insufficiently in recent literature: Following their individual preferences, the board members execute their responsibilities dependent on their personal relationship with the executives. In one rare example, Miller (2002) shows that the monitoring function of board members is performed dependent on their relationship with the chief executive. This counts especially 
for the relationship between the CEO and the chairman, as the following quote of a chairman of an industry association demonstrates.

The whole thing is a game between the president and the director. Generally, the CEO reconciles the structure and priorities with the resources. The president says what he wants and the CEO has the operative responsibility for the implementation.

Therefore, the personal performance of these two positions is very important for governance of the organizations in general. One president of a professional organization pointed out this correlation as one of the major problems of nonprofit governance.

The relationship between management and board is far too strongly dependent on individual performances. As an association we are too small to assure governance independent of individuals. In our case the company culture of the president was transferred into the association.

Although the respondents acknowledged a clear separation of strategic and operative leadership between board and CEO, the relationship between them can be explained more likely by stewardship theory than agency theory (Donaldson and Davis, 1991).

A major role of the board is the supervision of the CEO and the executive staff. In six of the ten interviewed organizations this role is performed by the president or a board committee (mostly president, vicepresident and one or two additional board members). In the other cases, two have a board committee, and in the last two associations, the entire board takes this responsibility. Generally, this role should be of high relevance for the board in order to assure strategic planning and financial control. From the perspective of the CEO, the supervision of the board gives him or her assurance for his or her work. But the results of the interviews show an interesting divergence. The statement, "The main task of the board is to control the CEO" was rated differently by board members and CEOs. While the CEOs confirmed the statement, their corresponding board members denied it in most cases. Additionally, only 3 board members mentioned a high relevance of this task, but 7 CEOs and 5 members described this task as very important. This divergence highlights the need of standardized role definitions in order to avoid ambiguity (Siebart, 2006).

In the next section we are going to combine the descriptive results of the case studies with the data from the interviews in order to develop an aggregated perspective of the findings and to detect evidence for the governance practice in trade associations and unions. While the descriptive data of the case studies offers insight into structural dimensions centrality, size and member type, the interviews contained information on governance issues, especially on questions of representation and checks and balances.

\section{Patterns of governance in trade associations and unions}

The following section is based on the figures presented in section 4. Looking at the average figures of the number of board members and of advisory boards, two general conclusions can be drawn. First, the average number of board members is much higher in trade associations with individual members. This might be a result of a higher heterogeneity in these organizations or be a consequence of different election modalities (e.g. 
one board member per x members). Second, the average number of advisory boards is clearly smaller in associations with a federalist structure. A reason for this difference can be the higher necessity for the members of centralistic associations to secure their influence through advisory groups, whereas members of federalist associations can execute their influence sufficiently through the statutes. These general lines help to distinguish four different patterns of governance structures in trade associations and unions that are influenced by structural dimensions of the overall organization (table 2).

Table 2: Patterns of governance in trade associations and unions

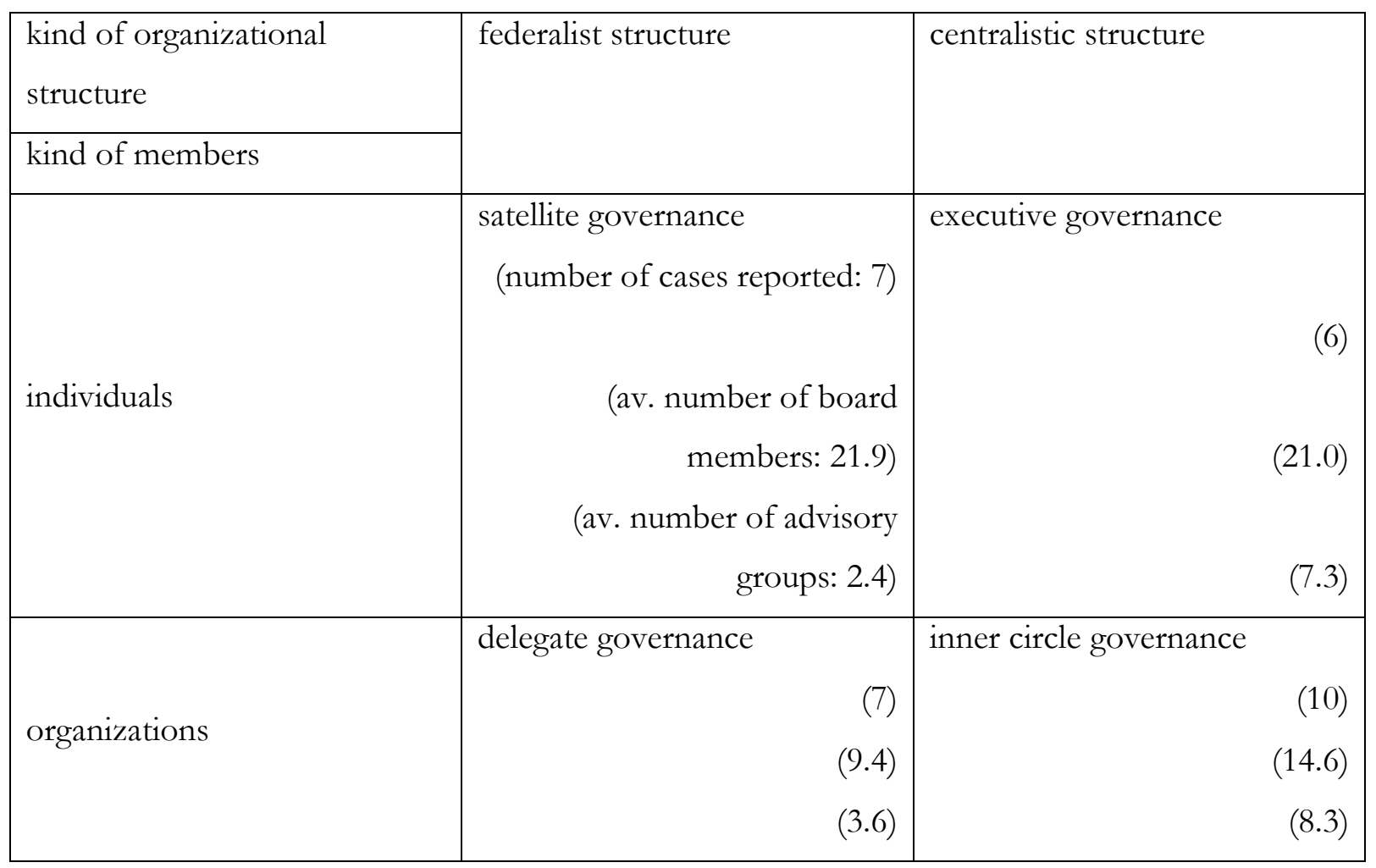

Satellite governance: Associations with this kind of governance structures have strong federal affiliates that control the core unit rather than vice versa. The large board represents the broad membership and the different federal organizations. The board acts more like a parliament with representatives of different regions or member groups (parties). The CEO of the core unit often has a strong influence on the board and serves as an intermediary between the national organization and the affiliates. The members have a stronger connection to the regional organization. Their attitude towards the core unit is often marked by skepticism. A typical example for this structure is a professional association that acts for several familiar professions with some large regional associations that control the national association e.g. architects and engineers.

Executive governance: In these structures the paid staff has the actual power. The board consists of regional representatives who should transfer the decisions made in the core unit into the affiliate organizations. Against the well prepared, highly political acting executives the board is too weak to pursue an active governance role. The strategic and operative work is done mainly by the paid staff with the assistance of advisory groups. This leads to a high potential of information asymmetry between the board and the paid staff. 
The members act dominantly like clients and rarely participate in statutory meetings. A classic example for this kind of governance structure is a national trade union e.g. railway employees.

Delegate governance: Associations with organizational members and federal structures tend to have strong boards with influential representatives of the member firms. Every regional affiliate sends their best candidates to the national board in order to maximize their influence. Generally, the paid staff is kept to a minimum due to efficiency expectations of the members. Usually, the board executes its governance role (accompanied by other member committees) very well. The CEO is not only responsible to the board of directors, but also to the affiliate organizations. An example is an industry association in a traditional industry with grown structures and country-wide appearance, e.g. metalworking industry.

Inner circle governance: In these structures the influence of regional affiliates is very low and limited to a minimum. Within the association we find a clear hierarchical structure with the core unit on top. The real influence comes from a few big companies that dominate the market and that expand their market domination into the association. They are strongly represented in the board (usually with their CEO) and the association's paid staff act like an external unit for these companies. The number of advisory groups is rather high as these groups serve to promote common interests and share industry information. An example for this pattern is an industry association of a service industry with a few market-dominating companies, e.g. telecommunication.

\section{Conclusion}

This article contributes to the question of governance actors in different institutional contexts (Saidel and Harlan, 1998). A major implication of these findings is that governance is not only a question of the boardmanagement relationship. In the case of trade associations and unions the different types of members play an important role. This is an important distinction between associations and service-based nonprofits that has been made insufficiently in the past. Board of directors should be aware of their associations' structure and realize the implications for effective governance.

The results of this study give insight on how structural mechanisms cause different patterns of governance in trade associations and unions. Based on the fact that associational members are both legitimating body and primary beneficiaries the governance responsibilities are distributed in a different manner than in service-based nonprofits. Especially, depending on the kind of structure and the kind of members, the governance tasks are executed by alternate groups of stakeholders.

The kind of structure is dominantly defined through the relationship between the national unit and the regional affiliates. This has a specific influence on the representation of members and the role of the advisory groups. In associations with centralized structures the advisory groups offer an additional opportunity for the members to articulate their interests, whereas in associations with federal structures this role is executed sufficiently by the delegate assembly. Further research should analyze the role of advisory groups in greater detail. 
The kind of members - differentiated into individual and organizational members - influences the composition of the board and the CEO-Board relationship. Associations with individual members tend to have larger boards and a more influential CEO, associations with organizational members have smaller and stronger boards which are often less representative. Starting from this point, a larger survey could add insight on which roles the association's members do execute in which organizational settings. This study suggests that the representatives of organizational members are more active as governance actors than individual members.

Governance in associations should be analyzed more deeply in future research. Especially, the influence of member representation on board composition and the board-CEO relationship is a subject of further research. It could help to ameliorate the understanding of decision making processes in this kind of organization. Especially, in strategy development the question of who has to be involved is a major issue in membership-based organizations. Additionally, the influence of organizational size on governance issues should be a major concern. Why do associations with individual members need larger boards? Which structural dimension drives the size of the board?

In recent time, the membership basis of professional associations and unions has been decreasing. Consequently, the structures of these organizations are changing, regional sections are being merged and less member contributions are available. The question arises as to what impact this development has on the governance structures. Would a change in the governance structures help to reverse the member behavior from exit option to voice option? Research on this kind of questions is still rare.

The results of this study establish a guideline for further empirical research, for testing different patterns, and for searching for a better understanding of the implementation of governance in trade associations and unions.

References

Abzug, R., and Galaskiewicz, J. "Nonprofit Boards: Crucibles of Expertise or Symbols of Local Identities?" Nonprofit and Voluntary Sector Quarterly, 2001, 30(1), 51-73. 
Akers, R. and Campbell, F. L. "Size and the Administrative Component in Occupational Associations." Pacific Sociological Review, 1970, Fall, 241-251.

Alexander, J. A., and Weiner, B. J. "The Adoption of the Corporate Governance Model by Nonprofit Organizations.” Nonprofit Management \& Leadership, 1996, 8(3), 223-242.

Anheier, H. K. "Foundations in Europe: A Comparative Perspective." in: Schlüter, A., Then, V., Walkenhorst, P. (eds). Foundations in Europe - Society Management and Law. London: The Directory of Social Change, 2001, 35-81.

Anheier, H. K., and Daly, S. (eds). The Politics of Foundations: A Comparative Analysis. London: Routledge, 2006.

Bailey, D. "The Strategic Restructering of Nonprofit Associations: An Exploratory Study." Nonprofit Management \& Leadership, 1992, 3(1), 65-80.

Blau, P. M., and Schoenherr, P. A. The Structure of Organizations. New York: Basic Books, 1971.

Bradshaw, P., Murray, V., and Wolpin, J. "Do nonprofit boards make a difference? An exploration of the relationships among board structure, process, and effectiveness." Nonprofit and Voluntary Sector Quarterly, 1992, (21)2, 227-249.

Brown, W. A. "Inclusive Governance Practices in Nonprofit Organizations and Implications for Practice" Nonprofit Management \& Leadership, 2002, (12)4, 369-386.

Brown, W. A. "Exploring the Association Between Board and Organizational Performance in Nonprofit Organizations.” Nonprofit Management \& Leadership, 2005, (15)3, 317-339.

Brown, W. A., and Iverson, J. O. "Exploring Strategy and Board Structure in Nonprofit Organizations." Nomprofit and Voluntary Sector Quarterly, 2004, (33)3, 377-400.

Bryce, H. J. "Nonprofits as Social Capital and Agents in the Public Policy Process: Toward a New Paradigm.” Nonprofit and Voluntary Sector Quarterly, 2006, 35, 311-318.

Callen, J. L., Klein, A., and Tinkelman, D. "Board Composition, Committees, and Organizational 
Efficiency: The Case of Nonprofits.” Nonprofit and Voluntary Sector Quarterly, 2003, (32)4, 493-520.

Carver, J. Boards that make a difference: A new design for leadership in nomprofit and public organizations. $2^{\text {nd }}$ Edition. San Francisco: Jossey-Bass, 1997.

Coleman, W., and Grant, W. "The Organizational Cohesion and Political Access of Business: A Study of Comprehensive Associations." European Journal of Political Research, 1988, 16, 255-269.

Cornforth, C. J. "What makes boards effective? An examination of the relationships between board inputs, structures, processes and effectiveness in non-profit organizations." Corporate Governance, 2001, (9)3, 217-227.

Cornforth, C. J., and Simpson, C. "Change and Continuity in the Governance of Nonprofit Organizations in the United Kingdom.” Nomprofit Management \& Leadership, 2002, (12)4, 451-470.

Donaldson, L., and Davis, J. "Stewardship Theory or Agency Theory: CEO Governance and Share-holder Returns." Australian Journal of Management, 1991, 16(1), 49-64.

Drucker, P. F. "Lessons for Successful Nonprofit Governance." Nomprofit Management \& Leadership, 1990, (1)1, 7-14.

Drucker, P. F. Managing in a time of great change. New York: Truman Tally Books/Plume, 1995.

Fama, E., and Jensen, M. "Separation of Ownership and Control." Journal of Law and Economics, $1983,26,301-325$.

Fletcher, K.B. "Effective Boards: How Executive Directors Define and Develop Them." Nonprofit Management \& Leadership, 1991, 2(3), 283-293.

Flick, U. "Design und Prozess qualitativer Forschung." in: Flick, U., von Kardorff, E., and Steinke, I. (eds). Qualitative Forschung: Ein Handbuch. Hamburg: Rowohlt, 2000, 252-264.

Friedman, A., and Phillips, M. "Balancing Strategy and Accountability." Nonprofit Management \& Leadership, 2004, 15(2), 187-204.

Fry, L. W. "Technology-Structure Research: Three Critical Issues.” Academy of Management Journal, 
$1982,25,532-551$.

Golensky, M. “The Board Executive Relationship in Nonprofit Organizations: Partnership or Power Struggle?" Nonprofit Management \& Leadership, 1993, 4(2), 177-191.

Harris, M. "Doing It Their Way: Organizational Challenges for Voluntary Associations." Nomprofit and Voluntary Sector Quarterly, 1998, 27(2), 144-158.

Hart, O. "Corporate Governance: Some Theory and Implications." The Economic Journal, 1995, 105, 678-689.

Herman, R. D., and Heimovics, R. D. “The Effective Nonprofit Executive.” Nonprofit Management \& Leadership, 1990, 1(2), 167-180.

Herzlinger, R. „Wirkungsvolle Aufsicht: Eine Anleitung für Vorstandsmitglieder von NonprofitOrganisationen." Verbands-Management, 1998, 1, 24-36.

Holland, T. P. "Board Accountability: Lessons from the Field." Nonprofit Management \& Leadership, 2002, 12(4), 409-428.

Holland, T., and Jackson, D.K. "Strengthening Board Performance." Nonprofit Management \& Leadership, 1998, 9(2), 121-134.

Houle, C.O. Governing Boards. San Francisco: Jossey-Bass, 1997.

Irle, M. Macht und Entscheidung in Organisationen: Studie gegen das Linien-Stab-Prinæip. Frankfurt a.M.: Jäger, 1971.

Jensen, M., and Meckling, W. “Theory of the Firm: Managerial Behaviour, Agency Costs and Ownership Structure.” Journal of Financial Economics, 3, 1976, 305-360.

Keasey, K., and Wright, M. (eds). Corporate Governance: Responsibilities, Risks und Remuneration. Chichester: Wiley, 1997.

Kepper, G. Qualitative Marktforschung, 2nd Edition. Wiesbaden: Gabler, 1996. 
Kieser, A. and Kubicek H. Organisation. 3rd Edition. Berlin/ New York: de Gruyter, 1992.

Knoke, D. Organizing for Collective Action: The Political Economics for Associations. New York: Aldine de Gruyter, 1990.

Kriesi, H. Le Système Politique Suisse. Paris: Economica, 1995.

Linder, W. Schweizerische Demokratie, Bern/ Stuttgart/ Wien: Haupt, 1999.

Lohmann, R. The Commons: New Perspectives on Nonprofit Organizations and Voluntary Action. San Francisco: Jossey-Bass, 1992.

Miller, J. L. "The Board as a Monitor of Organizational Activity." Nonprofit Management \& Leadership, 2002, 12(4), 429-450.

Murray, V., Bradshaw, P., and Wolpin, J. "Power in and Around Nonprofit Boards: A neglected Dimension of Governance.” Nonprofit Management \& Leadership, 1992, 3(2), 165-182.

O’Neill, M. "Philanthropic Dimensions of Mutual Benefit Organizations." Nonprofit and Voluntary Sector Quarterly, 23(1), 23-44.

Ostrower, F., and Stone, M. M. “Governance: Research Trends, Gaps, and Future Prospects.” in: Powell, W. W., and Steinberg, R. (eds). The Nonprofit Sector: A Research Handbook. 2nd Edition. New Haven: Yale University Press, 2006, 612-628.

Preston, J. B., and Brown, W. A. "Commitment and Performance of Nonprofit Board Members.” Nonprofit Management \& Leadership, 2004, 15(2), 221-238.

Saidel, J. R. "Expanding the Governance Construct: Functions and Contributions of Nonprofit Advisory Groups.” Nonprofit and Voluntary Sector Quarterly, 1998, 27(4), 421-436.

Saidel, J. R., and Harlan, S. L. "Contracting and Patterns of Nonprofit Governance." Nonprofit Management \& Leadership, 1998, 8(3), 243-259.

Schnyder, S. “Zur statistischen Erfassung des Dritten Sektors in der Schweiz im Rahmen der 
Volkswirtschaftlichen Gesamtrechnung." in: Schauer, R., Blümle, E.-B., Witt, D., and Anheier, H. K. (eds). Nonprofit-Organisationen im Wandel, Linz: Trauner, 2000, 313-322.

Schwarz, P. Management von Nonprofit-Organisationen. 2nd Edition, Bern/ Stuttgart/ Wien: Haupt, 1996.

Schwarz, P. Organisation in Nonprofit Organisationen. Bern/ Stuttgart/ Wien: Haupt, 2005.

Siebart, P.: Corporate Governance von Nonprofit-Organisationen. Bern/ Stuttgart/ Wien: Haupt, 2006

Standley, A. "Reinventing a Large Nonprofit: Lessons from Four Voluntary Health Associations." Nonprofit Management \& Leadership, 2001, 11, 305-320.

Streeck, W. "Interest Heterogenity and Organizing Capacity: Two Logics of Collective Action?" in: Czada, R., and Windhoff, A. (eds). Political Choice: Institutions, Rules, and the Limits of Rationality. Boulder: Westview, 1991, 161-197.

Tschirhart, M. "Nonprofit Membership Associations." in: Powell, W. W., and Steinberg, R. (eds). The Nonprofit Sector: A Research Handbook. 2nd Edition. New Haven: Yale University Press, 2006, 523-541.

Van de Fen, A. H., and Ferry, D. C. Measuring and Assessing Organizations. New York: Wiley, 1980.

Watson, D. Managers of Discontent: Trade Union Officers and Industrial Relations Managers. London: Routledge, 1988.

Williamson, O. E. The Mechanisms of Governance. Oxford: Oxford University Press, 1996.

Wood, M. M. “Is Governing Board Behavior Cyclical?” Nonprofit Management \& Leadership, 1992, 3(2), 139-163.

Yin, R.K. Case Study Research: Design and Methods, Thousand Oaks: Sage, 2003.

Young, D. R. Casebook of Management for Nonprofit Organizations: Entrepreneurship and Organizational Change in the Human Services. New York: Haworth Press, 1985. 
Young, D.R., Bania, N., and Bailey, D. "Structure and Accountability: A Study of National Nonprofit Associations." Nonprofit Management \& Leadership, 1996, 6(4), 347-365. 